Canadian

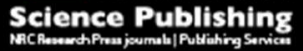

Botany

Botanique

\title{
Seedling recruitment in subalpine grassland forbs: Predicting field regeneration behaviour from lab germination responses
}

\begin{tabular}{|r|l|}
\hline Journal: & Botany \\
\hline Manuscript ID & cjb-2016-0022.R2 \\
\hline Manuscript Type: & Article \\
\hline Date Submitted by the Author: & 15 -Jun-2016 \\
\hline Complete List of Authors: & $\begin{array}{l}\text { Vandvik, Vigdis; Universitetet i Bergen Det Matematisk-naturvitenskapelige } \\
\text { Fakultet, Department of Biology } \\
\text { Elven, Reidar; Universitetet i Oslo Det Matematisk-naturvitenskapelige } \\
\text { Fakultet, Natural History Muesum } \\
\text { Töpper, Joachim; Universitetet i Bergen Det Matematisk- } \\
\text { naturvitenskapelige Fakultet, Department of Biology }\end{array}$ \\
\hline Keyword: & $\begin{array}{l}\text { Environmental cueing, generalized mixed models (GLMM), seedling } \\
\text { emergence, seedling mortality, seed size }\end{array}$ \\
\hline
\end{tabular}

\section{SCHOLARONE}

Manuscripts 
Vandvik et al., - Recruitment-regulating mechanisms in subalpine grassland

Article:

Seedling recruitment in subalpine grassland forbs: Predicting field regeneration behaviour from lab germination responses

Vigdis Vandvik, Reidar Elven and Joachim Töpper

Vigdis Vandvik, Joachim Töpper. Department of Biology, University of Bergen, Tormøhlensgate 53A, N-5008 Bergen, Norway.

Reidar Elven. Natural History Museum, University of Oslo, Sars gate 1, Tøyen, 0562 Oslo, Norway

Running title: Vandvik, et al. Recruitment-regulating mechanisms in subalpine grassland

Corresponding author: Vigdis Vandvik (e-mail vigdis.vandvik@,uib.no) 
Vandvik et al., - Recruitment-regulating mechanisms in subalpine grassland

Abstract: Environmental cueing that restricts seed germination onto times and places where mortality risk is relatively low may have considerable selective advantage. The predictive power of lab germination responses for field regeneration behaviour is rarely tested. We screened 11 alpine grassland forbs for germination behaviours predictive of microsite and seasonal selectivity, and seed carry-over across years. The predictions were tested in a field experiment. Germination in the lab ranged from $0.05 \%$ to $67.9 \%$, and was affected by light (5 species), temperature (6), fluctuating temperatures (4), moist chilling prior to germination (cold-stratification) (6), and dormancy-breaking by means of gibberellic acid (8). Seedling emergence in the field varied from $0.1 \%$ to $14.1 \%$, and increased in low-competition microsites (bare-ground gaps and cut vegetation; 7 species), and showed seasonal timing (1 in autumn and 1 in spring), and seed carry-over across years (7). Lab germination responses successfully predicted microsite selectivity in the field and to some extent seed carry-over across years but not seasonal timing of germination. Gap-detecting species were generally small-seeded, low-growing, and found in unproductive habitats. Larger-seeded species germinated in all microsites but experienced increased mortality in high-competition microsites. Seed carry-over across years was lower in alpine specialists than in more widelydistributed species.

Keywords: Environmental cueing, generalized mixed models (GLMM), seedling emergence, seedling mortality, seed size. 
Vandvik et al., - Recruitment-regulating mechanisms in subalpine grassland

\section{INTRODUCTION}

A seed that germinates 'bets its life', in a very real sense, on the favourability of the environment until the plant has accumulated sufficient photosynthetic capital to reproduce or to tolerate a wider range of conditions (Angevine and Chabot, 1979; Donohue, 2005).

Clearly, strategies or life-history traits that decrease the probability of encountering unacceptable growth conditions during germination and establishment may have a strong selective advantage.

Seedling mortality risk is not randomly distributed in space and time, but varies between vegetation types, between microsites with different water, light, and nutrient availabilities, and between seasons (Mack and Pyke, 1984; Forbis, 2003; Graae et al., 2011, Vranckx and Vandelook, 2012; Milbau et al., 2013). This opens up the possibility for regulating germination in ripe seeds through highly specific germination requirements often referred to as environmental cueing responses. The effectiveness of such responses depends critically on the ability of seeds to sense and react appropriately to environmental cues that correlate with times or places where the survival probability is comparatively high. It has been shown that germination may be initiated or inhibited by minute differences in factors such as temperature regime, light intensity or spectral quality, soil nutrients, or moisture (reviewed in Fenner, 2000; Baskin and Baskin, 2014). Not only is mortality risk affected by the conditions the seed is facing at any particular time or place, it is also affected by the variability in environmental conditions over time, such as between-year variation in climatic conditions (see Donohue, 2005; Muller et al., 2011). Under such circumstances germination may be regulated through dormancy, which functions to block germination and thus render seeds inactive under conditions that are suitable for germination (i.e., dormancy sensu Vleeshouwers et al., 1995; Willis et al., 2014). For example, environmental cueing 
Vandvik et al., - Recruitment-regulating mechanisms in subalpine grassland responses may be modified by exposure to dry heat or moist chilling prior to germination (warm- and cold-stratification, sensu Baskin and Baskin, 2014), enabling germination to be postponed until after a specific event has occurred, such as the passing of a cold or dry season, a fire, etc. (often referred to as 'predictive dormancy'). In situations where mortality risk is not predictably related to the environmental variation the efficiency of environmental cueing and predictive dormancy responses responses breaks down. Under such circumstances, bet-hedging strategies (Venable and Brown, 1988; Philippi, 1993), leaving a fraction of the seeds dormant through periods of good germination conditions, and thereby ensuring a carry-over of seeds across years and the build-up of persistent seedbanks may buffer populations against stochastic high-mortality events (see Willis et al., 2014). Relative to seeds that germinate at the first physiological opportunity, both environmental cueing and dormancy (predictive or not) will function to increase the time to germination in ripe seeds, and hence have costs in terms of population growth rate (Donohue et al., 2010). As the ability to escape predation and disease is inversely correlated with seed size (Leishman et al., 2000), we should expect species that exhibit such germination-delaying mechanisms to be relatively small-seeded.

Variation in seed germination responses in lab experiments has been found at many scales: within populations (Andersson and Milberg, 1998), species (Meyer and Monsen, 1991; Schütz and Milberg, 1997; Cavieres and Arroyo, 2000; Wagmann et al., 2012; Spindelböck et al., 2013), families (Schütz, 1999), communities (Grime et al., 1981; Olff et al., 1994; Washitani and Masuda, 1990), and regions (Baskin and Baskin, 2014). Few studies have explicitly tested the predictive power of lab germination responses for field germination behaviour directly, however, and some of the studies that do have had difficulties detecting field consequences of seemingly interpretable lab germination responses (e.g., Grubb, 1988; Reader and Buck, 1990; Olff et al., 1994; Schütz and Milberg, 
Vandvik et al., - Recruitment-regulating mechanisms in subalpine grassland 1997; Milberg et al., 2001; Mondoni et al., 2015; reviewed in Donohue 2005, Donohue et al., 2010). This suggests that it is difficult to accurately simulate the complex conditions experienced by seeds in the field. The aim of this study is to explicitly test for links between the ecophysiological germination responses of species in lab germination experiments and their recruitment behaviours in the field.

Our study system is the semi-natural subalpine grasslands in Scandinavia, created and maintained by centuries of low-intensity free-range grazing by domestic herbivores ('summer farms', see Austrheim and Eriksson, 2001) These grasslands occur as 'habitat islands' scattered throughout the subalpine and low-alpine regions of Scandinavia and support a rich and characteristic flora including forbs and grasses typical of low productivity semi-natural grassland along with subalpine and alpine plants (Austrheim and Eriksson, 2001; Vandvik, 2004). In perennial grasslands, competition from established plants poses a major challenge for successful seedling establishment. Thus, temporary, low-competition microsites created by individual plant deaths or small-scale disturbances are important for seedling recruitment (Vandvik, 2004; Graae et al., 2011, Hoyle et al., 2013; Milbau et al., 2013) and diversity maintenance (Vandvik and Goldberg, 2006) in subalpine grasslands. While the spatial and temporal occurrence of such microsites is stochastic, removal of the plant sward modifies the immediate environment of a seed at the soil surface in predictable ways: changing light spectral quality (e.g., red to far-red ratios) and increasing light transmittance, increasing daily maximum temperature and thermal amplitude, etc.. Consequently, seedling survival probability may be increased by light requirements for germination, or for high or fluctuating temperatures, which may function as gap-detecting mechanisms (Grime et al., 1981; Rice, 1985; Olff et al., 1994; Kotorová and Lepš, 1999; Bullock, 2000; Battla, et al., 2001; Vranckx and Vandelook, 2012). In the highly seasonal climates of subalpine regions, seedling mortality risk also varies predictably throughout the 
Vandvik et al., - Recruitment-regulating mechanisms in subalpine grassland year, opening up the possibility for temporal cueing mechanisms (Thompson and Grime, 1979; Olff et al., 1994; Masuda and Washitani, 1990; Donohue et al., 2005; Willis et al., 2014). For example, a requirement for prolonged moist chilling prior to germination, especially when combined with germination cued to high temperatures, could inhibit germination in freshly-shed seed in the autumn and effectively delay seed regeneration until the following spring (Grime et al., 1981; Baskin and Baskin, 2014). Finally, alpine regions also have highly variable summer climates, with a risk of sudden snow-fall and frost throughout the short growing season and thus a possibility of unpredictable 'bad years' both in terms of seed production and seedling survival. It has been argued that such climatic stochasticity may select for 'bet-hedging' dormancy strategies (Philippi, 1993; Donohue, 2005, Willis et al., 2014) that ensures a carry-over across years of a fraction of the viable seeds. While the empirical support for this hypothesis has largely been been anecdotal, a recent study of long-term germination and seed bank demographies support delayed germination via seed dormancy as a bet hedging strategy for all the 12 most common species a desert annual community (Gremer and Venable, 2014).

To explore these potential relationships between ecophysiological germination responses in the lab and field regeneration behaviour, we selected 11 herb species representing the wide range of life-histories, biogeographic distributions and ecological characteristics found in subalpine semi-natural grasslands. For each of these species we tested for germination responses to light, temperature and moist chilling pre-treatment in a lab experiment, and we quantified seedling emergence and mortality in the field over two years under four experimental treatments that represent a gradient in competitive regimes (from intact vegetation via cutting to bare-ground gaps). Based on the literature reviewed above, we expect small-seeded, alpine, grassland specialists, and low-stature species to have stronger light and/or temperature germination responses that allow them to detect low- 
Vandvik et al., - Recruitment-regulating mechanisms in subalpine grassland competition microsites such as short vegetation or bare-ground gaps in the vegetation sward, and hence to show stronger responses to vegetation removal than larger-seeded species in the field. In contrast, we expect larger-seeded and habitat generalist species to lack these germination responses and hence to recruit from seed across a wider range of microhabitats. We expect species lacking a requirement for moist chilling prior to germination, combined with low minimum temperatures for germination to recruit immediately following seed-shed in the autumn, and we expect species with a requirement for moist chilling prior to germination and/or high minimum temperature for germination to recruit predominantly in the following spring, after snow-melt. Further, we expect species with non-predictive dormancy and/or low or slow germination in the lab even under 'optimal' germination treatments to show the greatest seed carry-over across years in the field.

\section{MATERIAL AND METHODS}

Study system

The study was carried out in subalpine grassland vegetation in eastern Norway, in the Vangrøftdalen valley, Os Municipality $\left(10^{\circ} 49^{\prime} \mathrm{E}, 62^{\circ} 37^{\prime} \mathrm{N}\right)$. The landscape is characterized by subalpine birch forest and extensive mire systems, with semi-natural grasslands ('summer farms', see Austrheim and Eriksson, 2001; Vandvik and Birks, 2002) scattered throughout. The grasslands are situated at altitudes of between $700-800$ meters above sea level (m.a.s.1.) surrounded by mountains reaching 1100 - 1200 m.a.s.l. The climate is continental and subalpine, with an annual precipitation of $504 \mathrm{~mm}$, maximum duration of the growing season from May to October, and mean temperatures during the growing season of $5.6^{\circ} \mathrm{C}$, $10.1^{\circ} \mathrm{C}, 11.4^{\circ} \mathrm{C}, 10^{\circ} \mathrm{C}$, and $6.1^{\circ} \mathrm{C}$, in May, June, July, August and September, respectively (www.DNMI.no). The semi-natural grasslands support a species-rich flora, 231 species of 
Vandvik et al., - Recruitment-regulating mechanisms in subalpine grassland

vascular plants have been recorded on the 87 summer farms in the Vangrøftdalen valley (V. Vandvik, unpublished data).

Species selection and plant material

We studied eleven species (Campanula rotundifolia L., Gentianella amarella L. Börner, Gentiana nivalis L., Geranium sylvaticum L., Knautia arvensis Coult., Potentilla crantzii Crantz. Fritsch, Primula scandinavica Brunn, Ranunculus platanifolius L., Trollius europaeus L., Veronica alpina L., and Viola biflora L.) that co-occur within perennial subalpine grasslands in the study area (nomenclature follows the International Plant Names Index (www.ipni.org/index.html). The species were selected to represent a range in seed mass, life histories (annual/biennial to long-lived clonal perennial), seed dormancy classes (physical, physiological, morphophysiological), established plant size, distributional patterns (alpine, lowland, or ubiquitous), regional abundances (scattered or common), habitat preferences (strictly grassland or generalist), bedrock requirements (basic vs. indifferent), and soil fertility requirements (low or high) (Lid and Lid, 2005) (Table 1).

Seeds (the whole single-seeded fruits of Knautia arvensis and Ranunculus platanifolius are denoted as seeds hereafter) were collected during the summer of 1998 from perennial grasslands, all within $150 \mathrm{~km}$ of the field experimental site (see below) and at 7001000 metres above sea level. Only ripe and undamaged seeds were used, and these were airdried at room temperature, and, to obtain enough seeds per sample for both the field and laboratory experiments, combined in bulk samples, each containing seeds from 1-4 different localities, and from at least 50 mother plants. This implies that our results should be interpreted as species-level responses, with no information about population or individuallevel variation. For the field germination experiment, 20 batches of 100 seeds were prepared and sown within two weeks from collection (see below). The remaining seeds were stored 
Vandvik et al., - Recruitment-regulating mechanisms in subalpine grassland dry in paper bags at $4^{\circ} \mathrm{C}$ until batches of 50 apparently ripe and undamaged seeds were placed on moist filter paper in a $100 \mathrm{~mm}$ seal-tight Petri dish for the lab experiments.

\section{Lab germination experiments}

Seed germination requirements were tested in four growth-chamber experiments, investigating the effect of (A) light and temperature, and (B) fluctuating temperatures, (C) a moist chilling pre-treatment (cold-stratification sensu Baskin and Baskin 2014), and (D) dormancy breaking by means of gibberellic acid, $\mathrm{GA}_{3}$. The treatment levels were chosen so as to be of relevance for the study system, subalpine grasslands in the boreal zone (see climate data above), as follows:

Light treatments were full light, using standard artificial greenhouse light for a photoperiod of 16 hours per day to match summer light conditions at our latitude, or darkness. Petri dishes receiving dark treatment were wrapped individually in two layers of aluminium foil, and these were opened and counted under a safe green light $(<0.05$ $\left.\mu \mathrm{mol} / \mathrm{m}^{2} \mathrm{~s}\right)$.

In experiments (A) and (B), four constant temperature regimes $\left(10^{\circ} \mathrm{C}, 15^{\circ} \mathrm{C}, 20^{\circ} \mathrm{C}\right.$ and $25^{\circ} \mathrm{C}$ ) and a diurnal cycle (16 hours at $25^{\circ} \mathrm{C}$ and 8 hours at $\left.10^{\circ} \mathrm{C}\right)$ were compared in light and darkness. The 24-hour temperature sums of the $20^{\circ} \mathrm{C}$ and $25 / 10^{\circ} \mathrm{C}$ treatments are identical; by testing germination responses to fluctuating temperature against germination at $20^{\circ} \mathrm{C}$ we investigate the effect of the diurnal variation per se.

Seeds were subjected to moist chilling in darkness at $4^{\circ} \mathrm{C}$ in a moist environment (achieved by keeping the filter paper moist and sealing the petri dishes, ensuring access to free water) for two months prior to experiments (A) and (B), and germinability in seed batches not subjected to the moist chilling pre-treatment (C) was included to quantify dormancy levels in fresh seeds (Grime et al., 1981; Baskin and Baskin, 2014). In experiment 
Vandvik et al., - Recruitment-regulating mechanisms in subalpine grassland

(C) fresh seeds (these were kept in dry storage during the moist chilling period, see above) were set to germinate at $20^{\circ} \mathrm{C}$ in light and darkness, using the germination of moist chilled seeds at $20^{\circ} \mathrm{C}$ in light and darkness as controls.

Treatment with gibberellins ( $\mathrm{GA}_{3}$ acids) has proven highly effective in dormancybreaking in a number of alpine species (e.g., Hoyle et al., 2013; and references therein) and for different kinds of dormancy (Baskin and Baskin, 2004), and experiment (D) was therefore included to indicate whether any important environmental cues that may break dormancy and initiate germination had been missed. In experiment (D), the Petri dishes were watered with $800 \mathrm{mg} \mathrm{L}^{-1} \mathrm{GA}_{3}$, (selected to be within the range reported in Hoyle et al., 2013 ) and set to germinate in light at $20^{\circ} \mathrm{C}$, using the germination of seeds exposed to a moist chilling pre-treatment at $20^{\circ} \mathrm{C}$ in light as controls.

For each factorial combination of treatments x species four replicate Petri dishes containing 50 seeds were used, for a total of 572 Petri dishes and 28600 seeds. Germination was recorded and seedlings removed after 2, 4, 6, 10, 16, 24, and 32 days. At each count, the positions of the Petri dishes were shuffled and water was added to maintain equal light and moisture levels and prevent drying at warmer incubation temperatures. The experiments were carried out at the Centre for Plant Research in Controlled Climate at the Norwegian University of Life Sciences (www.nmbu.no/tjenester/sentre/skp). Six growth chambers were available, and in order to obtain replication for temperatures, experiments (A) and (B) were run twice with different chamber $\mathrm{x}$ temperature combinations in the two replicate runs. There was no measurable chamber-to-chamber difference in light intensity and spectral quality, or any differential effect of the light treatments on temperatures within Petri dishes (monitored by the technical staff at the Centre). The raw data are available in the Dryad Digital Repository doi:10.5061/dryad.04f8c (Vandvik et al., 2016). 
Vandvik et al., - Recruitment-regulating mechanisms in subalpine grassland

\section{Seed regeneration in perennial grassland}

A field experiment to investigate the seedling emergence and mortality of the 11 species in contrasting grassland microsites was set up at a semi-natural grassland at Såttåhaugen $\left(10^{\circ} 49^{\prime} 50^{\prime \prime} \mathrm{E}, 62^{\circ} 37^{\prime} 80^{\prime \prime} \mathrm{N}\right)$ at 880 m.a.s.1.. The site was chosen to be as ecologically and floristically representative of the subalpine grasslands in the area as possible. Seven of the study species, Campanula rotundifolia, Gentiana nivalis, Geranium sylvaticum, Potentilla crantzii, Trollius europaeus, Veronica alpina, and Viola biflora are locally present; the remaining occurring at similar sites nearby. In order to minimize germination of the selected species from the seed bank, or from seeds dispersing into the plots, the experimental blocks were located in a patch of vegetation where the study species were relatively uncommon (but supporting characteristic summer farm grassland vegetation, indicating suitable habitat for the target species, cf. Vandvik, 2004). Four experimental treatments that reflect different environmental and competitive settings for seeds and seedlings were compared; bare-ground gaps with both above- and below-ground plant parts removed, vegetation cut at ground level $(0 \mathrm{~cm})$, vegetation cut at $5 \mathrm{~cm}$ above ground, and nontreated plots with a field layer of ca. $20 \mathrm{~cm}$ in height. These are referred to as 'microsites' hereafter. In October 1998, a fully factorial randomized block design with five replicate blocks, each containing a grid of $4425 \mathrm{~cm}$ x $25 \mathrm{~cm}$ plots, was set up. Each combination of species $\mathrm{x}$ treatment was represented once within each block, and batches of 100 recently collected seeds (see above) were sown into the central $20 \mathrm{~cm} \times 20 \mathrm{~cm}$ of each plot, for a total of 22000 seeds and 220 plots.

In 1999 and 2000, seedling emergence and mortality were recorded as the grassland sward closed at the end of spring (late June), and at the end of the growing season (late August). No precautions were taken against seed predation or seedling herbivory, and the 
Vandvik et al., - Recruitment-regulating mechanisms in subalpine grassland observed emergence and survival hence reflect those realized by naturally-dispersed seeds and seedlings at the site. Due to the remote location of the field site, more frequent censuses were not possible. At each census the position of each plant or seedling of the 11 sown species was measured to the nearest $\mathrm{cm}$, and the presence of cotyledons, the number of leaves, and the height of each individual recorded. The seedlings were marked with plastic rings to ensure that they would be recognised as 'old' in subsequent censuses. Seedlings of the target species found in plots where they had not been sown were also registered to estimate germination from naturally occurring seeds in the seed bank or seed rain (i.e., the other plots constitute the controls for each target species. Mean number of seedlings in the controls were subtracted from the mean number of seedlings in the treated plots to obtain numbers germinated from the sown seeds. The natural recruitment was always very low always less than $5 \%$ of the sown seed emergence, and this had minimal impact on the results and analyses). By comparing data across census dates, new germinants could be identified, and mortality and survival determined. New germinants of a sown species in the second year reflects emergence after seed carry-over. After each census the ground level and $5 \mathrm{~cm}$ plots were cut. This did not affect seedlings directly as they were generally very small $(<1 \mathrm{~cm})$ and grew slowly. The raw data are available in the Dryad Digital Repository doi:10.5061/dryad.04f8c (Vandvik et al., 2016).

\section{Statistical analyses}

We used generalized linear mixed effects models (GLMM) with binomial error structure to test for effects of treatments on germination responses over time in the lab experiment, and on seedling emergence and mortality over the seasons in the field experiment. In the lab experiment, germination and success versus failure (i.e., a binomial response) was used as logistic response, the experimental treatments were included as 
Vandvik et al., - Recruitment-regulating mechanisms in subalpine grassland categorical variables and time since onset of the experiment as a numeric variable. First, a model using the entire germination time series was run for each species and experiment. Here the main effects of experimental factors and interactions between experimental factors represent effects on the onset of germination, while interactions of experimental factors with time represent effects on the steepness of the curves (i.e. germination rate (speed) or the uniformity of germination timing in the seedlot). The main effect of time alone does not merit interpretation as it simply reflects that germination is a cumulative process through time. In experiments (A) and (B) Petri dish nested within growth chamber were used as random effects to account for variation issued from the different growth chambers and for the pseudo-replication issued from the repeated measurements per Petri dish in the time series. Experiments (C) and (D) were performed in a single growth chamber and hence only Petri dish was used as a random effect. Second, a model using differences in final germination percentages (total number of seeds germinated) was run. These models only had the experimental treatments and their interactions as fixed effects. For experiments (A) and (B) we used growth chamber as a random effect, for experiments (C) and (D) there were no random effects and we hence used a generalized linear model (GLM) instead. In the field experiment, successes versus failure of germination and mortality between consequent censuses were used as dependent variables, treatment and season as fixed factors, and experimental blocks as random factors. Spearman rank correlations were used to explore the relations between field emergence and mortality and seed mass.

In all models, we accounted for overdispersion, when indicated by the residual deviance, using an additional single-observation random effect in the GLMMs and a quasibinomial distribution in the GLMs. All models were simplified in a backwards selection procedure using likelihood ratio tests and ANOVA tables of the final models were built using Wald II $\chi^{2}$ tests in the GLMMs and $\chi^{2}$ tests in the GLMs. The p-values for 
Vandvik et al., - Recruitment-regulating mechanisms in subalpine grassland individual-level comparisons given in the text are based on the $\mathrm{Z}$ statistic. All analyses were performed in R 3.1.1. (R Core Team, 2014) using the package lme4 for the GLMMs (Bates et al., 2014) and the package car for Wald tests (Fox and Weisberg, 2011)

\section{RESULTS}

Germination responses in the lab

Out of the 28600 seeds sown, 6077 germinated during the 32-day lab experiment. Germination onset, germination rates, and final germination varied greatly among species, where final germination ranged from $0.05 \%$ (Ranunculus platanifolius) to $67.9 \%$ (Viola biflora) averaged over all treatments, and among treatments, where it ranged from $9.5 \%$ $\left(10^{\circ} \mathrm{C}\right.$, darkness) to $38.1 \%\left(20^{\circ} \mathrm{C}\right.$, light, $\left.\mathrm{GA}_{3}\right)$ averaged over all species (Figs. 1,2$)$.

For three species, Campanula rotundifolia, Potentilla crantzii, and Primula scandinavica, light was the experimental factor that affected germination most strongly, and for these species germination was both earlier and approximately three times higher in light than in darkness $(40.9 \%$ vs. $13.9 \%, 16.9 \%$ vs. $6.4 \%$, and $58.9 \%$ vs. $20.3 \%$, respectively, averaged over all temperatures, Tables 2A, 3A, Fig. 1). In Campanula rotundifolia, Knautia arvensis and Veronica alpina there were interactions between light and temperature for final germination (Table 3A), with temperature optima being higher in light than in darkness for C. rotundifolia and V. alpina (Fig. 1). In contrast, Knautia arvensis had lower (17.4\% vs. $21.9 \%$ ) and slower germination in light than in darkness at $10^{\circ} \mathrm{C}$, but there were no differences in final germination in the warmer temperatures (Fig. 1). In Geranium sylvaticum and Viola biflora there was no effect of light on germination.

Viola biflora was the only species that germinated equally well under all temperature regimes, and for the other species germination rates and final percentage generally increased with temperature but the responses differed strongly among species (Table 2A, Fig. 1). 
Vandvik et al., - Recruitment-regulating mechanisms in subalpine grassland Geranium sylvaticum also germinated at similar rates across temperature treatments, but the onset of germination was earlier and final germination higher at $25^{\circ} \mathrm{C}$ than at $10^{\circ} \mathrm{C}$ (Table 2A, 3A, Fig. 1). In Campanula rotundifolia germination was generally faster and higher at higher temperatures, but the only significant difference was between final germination percentage $10^{\circ} \mathrm{C}$ and $25^{\circ} \mathrm{C}$ (Table 3A, Fig. 1) In Knautia arvensis germination onset, germination rate, and final germination percentage increased with temperature, so that final germination was lower at $10^{\circ} \mathrm{C}$ than at $15^{\circ} \mathrm{C}, 20^{\circ} \mathrm{C}$, and $25^{\circ} \mathrm{C}$ (Table $2 \mathrm{~A}, 3 \mathrm{~A}$, Fig. 1). In Veronica alpina, germination was slow and low at $10^{\circ} \mathrm{C}$ and rapid and high above $15^{\circ} \mathrm{C}$, so that germination at the lowest temperature differed from the others (Table 2A, 3A, Fig. 1), but there were no differences between germination at $15^{\circ} \mathrm{C}, 20^{\circ} \mathrm{C}$, and $25^{\circ} \mathrm{C}$. Seeds of Potentilla crantzii and Primula scandinavica did not germinate at $10^{\circ} \mathrm{C}$, and in both species germination increased with temperature so that final germination at $15^{\circ} \mathrm{C}$ was lower than at $20^{\circ} \mathrm{C}$ and $25^{\circ} \mathrm{C}$ in P. crantzii (Table 2 A, Fig. 1) whereas germination onset, rates and percentages differed between all temperatures in $P$. scandinavica (Table 2A, 3A, Fig. 1).

Only one species, Potentilla crantzii, had a significantly positive response to fluctuating temperatures, where germination was both faster and 2.3 -fold higher than at $20^{\circ} \mathrm{C}$ $(40.8 \%$ vs. $18.0 \%)($ Table 2B, 3B, Fig. 1). In Campanula rotundifolia germination was slower, and in Primula scandinavica it was lower under fluctuating temperatures compared to constant temperatures (Table 2B, 3B, Fig. 1).

No species had absolute requirements for moist chilling pre-treatment, and the magnitude of the responses differed considerably (Fig. 2). In Veronica alpina, Primula scandinavica, and Viola biflora final germination was increased (2.4-fold, 6.9-fold, and 32fold, respectively) and in Veronica alpina, Knautia arvensis and Viola biflora the onset of germination was earlier in seeds that has been exposed to moist chilling prior to germination, indicating that these seeds are at least partially dormant when shed (Table 2C, 3C, Fig. 2). In 
Vandvik et al., - Recruitment-regulating mechanisms in subalpine grassland

Geranium sylvaticum and Potentilla crantzii, however, the final germination of moist chilled seeds was actually lower than in fresh seeds (Table 3C, Fig. 2).

Four species, Gentiana nivalis, Gentianella amarella, Trollius europaeus, and Ranunculus platanifolius, germinated poorly $(<5 \%)$ under all temperature, and light treatment, and both with and without the moist chilling pre-treatment. In the first three species, germination at $20^{\circ} \mathrm{C}$ was high in seeds treated with $\mathrm{GA}_{3}(34 \%, 46 \%$, and $93 \%$, respectively) (Table 2D, Fig. 2). Germination of Geranium sylvaticum at $20^{\circ} \mathrm{C}$ increased 2.4fold, from $17 \%$ to $45 \%$, by $\mathrm{GA}_{3}$. This implies that the seeds were alive and germinable, but that our lab treatments were unable to mimic the field conditions or cues that break dormancy and initiate germination in these species. The remaining six species germinated equally well, or better, under some combination of other experimental treatments in the lab than under the $\mathrm{GA}_{3}$ treatment, indicating that our lab experiment successfully mimics the environmental cues regulating the germination in these species.

\section{Seedling emergence and mortality in subalpine grassland}

Seedlings of all 11 species emerged in the field experiment and a total of 1071 seedlings out of the 22000 seeds sown were recorded over two years, giving an overall mean seed emergence percentage of $4.9 \%$ (Table 4). In total, 50 seedlings were registered in plots where they had not been sown (Campanula rotundifolia [11], Knautia arvensis [1], Trollius europaeus [1], and Viola biflora [36]). As all plots were searched for all species, the 'control' area is 10 times larger than the sown area for each species, the background regeneration of our species was very low $(<1: 20$ of the sown seedling densities in all cases) and was not considered further.

Significant differences in seedling emergence between microhabitats were found for seven species, Campanula rotundifolia, Gentianella amarella, Potentilla crantzii, 
Vandvik et al., - Recruitment-regulating mechanisms in subalpine grassland Ranunculus platanifolius, Trollius europaeus, Veronica alpina, and Viola biflora (Table 4). All these, had the highest emergence in bare-ground plots, except for Viola biflora which had high emergence in all but the $0 \mathrm{~cm}$ cut microsite. In addition, Primula scandinavica and Gentiana nivalis regenerated poorly in the field, but the few seedlings that did appear were all found in the $0 \mathrm{~cm}$ cut and gap microsites (Table 4). Differences in seedling mortality among microhabitats were found in four species (Campanula rotundifolia, Geranium sylvaticum, Viola biflora, and Ranunculus platanifolius ), which all had significantly reduced mortality in one or more of the gap or cut microsites relative to the controls (Table 4). One species, Knautia arvensis recruited and survived equally well across all microsites (Table 4).

Newly emerged seedlings were recorded in every census, but less than 40 individuals were encountered in spring 1999, and these were marked, but not analysed statistically. New seedlings of Gentianella amarella were only encountered in the autumn censuses, whereas emergence of Ranunculus platanifolius and Trollius europaeus peaked in the second year (in the spring 2000, and spring + autumn 2000 censuses, respectively) (Table 4). Overall, seedling mortality was higher $(\mathrm{P}=0.0231)$ during the winter (between the autumn 1999 and spring 2000 census) than during the summer (between spring and autumn 2000) (Table 4). This trend could be traced down to the species level for Ranunculus platanifolius and Geranium sylvaticum, and weakly, but not significantly for, Campanula rotundifolia, Gentiana nivalis, Knautia arvensis, Potentilla crantzii, Trollius europaeus, and Viola biflora.

These interactive effects of microsites and time on seedling emergence and mortality give rise to a variety of seedling recruitment trajectories in the 11 target species (Fig. 3). Seedlings of all species recruited gradually throughout the duration of the study, and at the end of the second growing season net recruitment varied from $<1 \%$ in Gentiana nivalis and Primula scandinavica to ca. $15 \%$ in Viola biflora, which also had its highest net recruitment 
Vandvik et al., - Recruitment-regulating mechanisms in subalpine grassland in the uncut control microsite. With the exception of Knautia arvensis, (which had no difference in either emergence or mortality) the remainder of the species had their highest net recruitment success in the bare-ground gaps.

\section{Linking lab germination responses, field recruitment, and species' ecology}

Three species germinated equally well under all light and temperature treatments in the lab and hence show no indication of gap-detecting germination responses (Geranium sylvaticum, Knautia arvensis, and Viola biflora) whereas seven species germinated significantly better under light, high or fluctuating temperatures, or had unresolved dormancy as indicated by strong gibberellic acid responses (Table 5). These germination responses predicted microsite selectivity in the field remarkably well (Table 5). Whereas microsite generalists tended to have large seeds, gap-recruiting species were smaller-seeded so that the generally positive correlation between emergence and seed mass was reversed in gaps (Table 4). Species with gap recruitment also tended to be small-statured and require basic and relatively infertile soils (Table 1,3 ). Seedling mortality across microsites in the field was not linked to gap recruitment or seed size (Table 4, 5).

Links between predicted and observed seasonal timing of germination were weak, and links between predicted and observed seed carry-over across years were also weak (Table 5). There were generally few links between both lab germination and field recruitment in relation to temporal cueing and species traits, but species with high altitudinal limits tended to have relatively low seasonal carry-over (Table 1, Table 5).

\section{DISCUSSION}

Our study documents large variation in lab responses to temperature, light, moist chilling pre-treatment, and gibberellic acid, and differences in field regeneration behaviour, among 11 co-occurring perennial forbs in subalpine grasslands in Norway. We find that 
Vandvik et al., - Recruitment-regulating mechanisms in subalpine grassland while germination responses under controlled conditions predict some seedling emergence behaviours in the field, notably in relation to microsite selectivity, many species did not perform as expected, especially in relation to temporal cueing of germination. This highlights the limitations of inferring germination and seedling establishment in the field based solely on experiments under highly controlled conditions (see also Muller et al., 2011). Below, we start by discussing potential strengths and weaknesses of the lab and field experiments, and move on to assess the ecological relevance of the lab germination responses for field regeneration behaviour of our target species.

\section{Methodological considerations}

Seven out of 11 species germinated to final germination $>20 \%$ under at least some combination of the light, temperature, and moist chilling treatments in the lab experiments, allowing us to make interpretations about their germination-regulating mechanisms. We included the gibberellic acid treatment as a proxy for unidentified germination requirements or sources of dormancy (Bell et al., 1995; 1999; Baskin and Baskin, 2004, Hoyle et al., 2013; Table 5). For six species we found no, weak, or negative responses in these tests and for these species we therefore conclude that the lab treatments adequately mimic the environmental cues that affect the breaking of dormancy and initiation of germination. For example, in Geranium sylvaticum, $\mathrm{GA}_{3}$ cancelled out a lower germinability in moist chilled relative to fresh seeds, and we can here identify the trigger of dormancy as the moist chilling prior to germination trials (Fig. 2). Our results suggest that the dormancy induced by moist chilling in Geranium sylvaticum is reversible, although the conditions that would reverse moist chilling-induced dormancy in nature are still unknown. The fact that dormancy was induced by moist moist chilling is consistent with Geranium sylvaticum having physiological dormancy (cf. Baskin \& Baskin, 2014). In Gentianella amarella, Gentiana nivalis, and 
Vandvik et al., - Recruitment-regulating mechanisms in subalpine grassland

Trollius europaeus (Fig. 2), germination was high in seeds treated with $\mathrm{GA}_{3}$, but low under all other treatments in the lab. For these species we conclude that the seeds were alive and germinable, but that the screening programme was not successful in mimicking the conditions needed to break dormancy and initiate germination. However, the existence of specific, albeit unknown, requirements suggests that it is likely that these species have narrow rather than wide regeneration niches, and may possess dormancy (Bueno et al., 2011). Ranunculus platanifolius germinated very poorly in the laboratory, both with and without $\mathrm{GA}_{3}$. This species has morphophysiological dormancy (Baskin and Baskin, 2014) and our seed treatments may hence be inadequate for preparing these seeds morphologically and physiologically to germinate.

Seedlings of all the sown species emerged in the field experiment, but seedling numbers were generally low. A potential methodological problem is that seedlings may have emerged and died between two consecutive censuses. However, other studies of seed regeneration in alpine and subalpine climates have found that seedling survival is often very high (all species $>50 \%$ (Chambers et al., 1990), 72\% during summer and 91\% during winter (Austrheim and Eriksson, 2003), up to $75 \%$ but variable, based on a field experiment and a literature review (Forbis, 2003), cf. Table 4), which implies that the seedling turnover within seasons is relatively low. Chambers et al. (1990) attribute this to the generally broad physiological tolerances of alpine species, and suggest that suitable conditions for germination are much more serious constraints for successful recruitment than seedling mortality in cold climates. If this is the case, then the seed germination characteristics should be a powerful predictor for establishment success. This premise is investigated in our study.

The cause of very low seed recruitment of Gentiana nivalis and Primula scandinavica in the field experiment is unclear. Seeds were collected from nearby populations in similar habitats, and Gentiana nivalis also occurs naturally within the 
Vandvik et al., - Recruitment-regulating mechanisms in subalpine grassland experimental site. Both Gentianella amarella and Potentilla crantzii emerged, despite being locally absent, suggesting that the site is suitable for species known to be demanding in terms of soil minerals, mycorrhiza, and general vegetation structure (Table 1; Lid and Lid, 2005). Gentiana nivalis germinated poorly under all experimental treatments in the lab, however, suggesting the species might have strong dormancy and/or very specific germination requirements.

\section{Gap-detecting germination responses}

Campanula rotundifolia, Potentilla crantzii, Primula. scandinavica, and Veronica alpina have light and fluctuating temperature responses that predict gap regeneration, while Geranium sylvaticum, Knautia arvensis, and Viola biflora were insensitive to these cues, indicating that seed regeneration should occur in all microsites (Table 5). These predictions were confirmed in the field (Table 5; Fig 4), indicating that vegetation cover and height are important determinants of seed regeneration in some species in these grasslands, and that a species' microsite sensitivity can be detected through lab screening for light and temperature responses. Four species did not germinate well in the lab, but strong $\mathrm{GA}_{3}$ responses (as found in two of these, Gentianella amarella, and Trollius europaeus, Table 2d) have previously been suggested to indicate narrow rather than wide regeneration niches (see Bell et al., 1995; 1999; Hoyle et al., 2013). This may be an explanation for the gap responses of these species (see Fig. 3; Table 5). The four species with strong light responses also respond to other cues in the lab, and responses interact (Table 2A), indicating that there is a tendency for a redundancy of germination-regulating mechanisms (c.f. Hilton, 1984; Milberg, 1997). For example, Primula scandinavica (among others, Fig. 1) has very high temperature requirements in darkness. This may also contribute to gap-detection, as, although sunshine may heat bare soil considerably even at relatively low air temperatures (Körner, 1999), and 
Vandvik et al., - Recruitment-regulating mechanisms in subalpine grassland so the probability of encountering high temperatures (e.g. above $20-25^{\circ} \mathrm{C}$ ) is high on bare ground but very low under a leaf canopy in subalpine climates where the air may never reach such high temperatures, even in mid-season. As predicted (e.g., Leishman et al., 2000), gapdetecting germination-regulation mechanisms were predominantly found in small-seeded species.

In contrast to the strong and interpretable light responses, the relatively weak effects of fluctuating temperatures in the lab were surprising, especially as this result is in contrast to strong responses documented elsewhere (Schütz, 1999; Vranckx and Vandelook, 2012; Baskin and Baskin, 2014). One possible explanation for this discrepancy could be that other temperatures, or different amplitudes than the regime investigated here $\left(25 / 10^{\circ} \mathrm{C}\right)$, are more effective. It is worth noting, however, that the diurnal temperature amplitudes of air decrease with altitude (Körner, 1999). As cueing is only physiologically possible when the environmental variation has a minimum range and predictability, the effectiveness and consequently the ecological importance of fluctuating temperature responses may decrease towards alpine climates.

All else being equal, we should expect that the capability of seedlings to withstand competition from the established sward should increase with seed mass (Leishman et al., 2000), resulting in smaller differences in seedling survival of large-seeded species between microsites (Ryser, 1993; Chambers, 1995). Our results may seem to contradict this, as three out of four species with significantly increased seedling mortality in intact sward microsites were relatively large-seeded; Geranium sylvaticum, Ranunculus platanifolius, and Viola biflora (Table 5). However, as discussed above, these species lack gap-detecting germination responses, and thus regenerate in all microsites, including the intact sward, from which many smaller-seeded species are absent. Thus, our results illustrate how environmental cueing mechanisms, when present, may decrease subsequent seedling mortality risk by restricting 
Vandvik et al., - Recruitment-regulating mechanisms in subalpine grassland germination to a narrower range of environmental conditions (i.e., the environmental cueing strategy is successful, sensu Donohue, 2005). Microsite selectivity cannot completely cancel out the survival advantage conferred by having large seeds, however, as the mortality-seed mass correlation is negative, even in bare-ground gaps (although not significantly so).

When both seedling emergence and seedling survival throughout the two-year experiment are taken into account, recruitment was higher in low-competitive microsites compared to the intact sward in nine out of eleven species, Knautia arvensis and Viola biflora being the exceptions (Fig. 3, Table 5). This indicates that microsite availability affects seedling recruitment, which in turn may contribute to our understanding of the mechanisms underlying impacts of disturbance on species composition and population persistence in alpine perennial grasslands (Vandvik and Goldberg, 2006; Graae et al., 2011; Milbau et al., 2013). The magnitude of the germination responses and field effects vary considerably among species, supporting the view that microsite selectivity during germination should be seen as quantitative rather than on-off traits (Hubbell et al., 1999; Bullock, 2000).

\section{Timing of recruitment within and across seasons}

Moist chilling requirements for germination are frequent in the seeds of temperate species worldwide (Grime et al., 1981; Olff et al., 1994; Washitani and Masuda, 1990; Vranckx and Vandelook 2012; Baskin and Baskin, 2014), and Meyer and Monsen (1991) argue that dormancy levels should also increase along gradients of increasing winter severity because the detrimental effect of untimely germination increases under harsh winter conditions. In light of this it may seem surprising that moist chilling responses were few and relatively weak in the 11 subalpine species investigated here. Also, in cases when such responses were found, the predicted links to the timing of seedling emergence to after 
Vandvik et al., - Recruitment-regulating mechanisms in subalpine grassland

snowmelt in the following spring was not supported in the field (Table 5). This could have at least three explanations.

First, the effectiveness of cueing depends critically on the range and predictability of environmental variation. In subalpine climates the thermal amplitude through the frost-free season is relatively low, in the study area the difference in mean temperature between the start of the growth season in May and the warmest month (July) is only $5.8^{\circ} \mathrm{C}$ (www.DNMI.no). This, coupled with high levels of stochasticity in weather between and within years in mountains (Körner, 1999), greatly reduces the physiological scope for precise timing of emergence in the field.

Second, seedling mortality risks and hence selective forces also vary with climate. In temperate climates, strategies that enable seedlings to appear in late autumn to early spring and avoid the hazards of summer drought may have a great selective advantage (Grime et al., 1981). In alpine climates drought is generally less problematic because the lower air temperatures decrease evaporation pressure (Körner, 1999). At the same time, late spring or early autumn frosts are more frequent and the frost-safe part of the season is shorter. Here, strategies that restrict the frost sensitive seedling stage to the safer mid-season, while avoiding the threats of early spring and late autumn, may give a selective advantage. This may explain why the seeds from our subalpine grassland populations had consistently high temperature thresholds for germination, and germination was significantly reduced at $15^{\circ} \mathrm{C}$ for several species, and at $10^{\circ} \mathrm{C}$ for all species but two, Geranium sylvaticum and Viola biflora (Fig. 1). High temperature thresholds for germination have previously been reported for northern as compared to southern species in Britain (Grime et al., 1981), and for mountain as compared to lowland populations within species (Cavieres and Arroyo, 2000; Spindelböck et al., 2013). This contrasts data from temperate species (e.g. Grime et al., 
Vandvik et al., - Recruitment-regulating mechanisms in subalpine grassland 1981; Washitani and Masuda, 1990; Kotorová and Lepš, 1999), where high germination at temperatures down to $2-4^{\circ} \mathrm{C}$ is common.

Third, the moist chilling regime applied in this study was short (eight weeks) relative to the winter season the seeds are likely to have been exposed to in the field (ca. eight months). Three species germinated to high percentages only after after the addition of $\mathrm{GA}_{3}$ (Gentianella amarella, Gentiana nivalis and Trollius europaeus), which is known to bypass dormancy in a number of alpine species (cf., Bueno et al., 2011; Hoyle et al., 2013). This could suggest that the moist chilling period may have been too short to break dormancy in these species. However, these species also did not emerge immediately after natural moist chilling in the field (i.e., in the spring), instead, all seedlings of Gentianella amarella and Gentiana nivalis emerged in the autumns, suggesting that other germination-regulating mechanisms are operating.

While seed carry-over across years was substantial and occurred in all species, the link with low and slow germination or unidentified dormancy mechanisms as reflected by $\mathrm{GA}_{3}$ response (Baskin and Baskin, 2004; Willis et al., 2014) is unclear from our data (Table 5; cf. Gremer and Venable, 2014). Dormancy is not the only process that may result in seed carry-over and build-up of persistent seed-banks, however, as germination niche and environmental conditions for seed survival are also important. Seed survival varies with climate as embryonic metabolic rates and the consumption of seed reserves decrease in cold climates (Murdoch and Ellis, 2000; Baskin and Baskin, 2014), along with the diversity of seed predators and pathogenic fungi (McGraw and Vaverek, 1989). Seed persistence in the soil may therefore be high in cold climates simply because germination requirements are not met, and/or because conditions for seed preservation are ideal. 
Vandvik et al., - Recruitment-regulating mechanisms in subalpine grassland

\section{Conclusions}

This study tests links between lab germination responses to light, temperature, moist chilling and gibberellic acid and field regeneration behaviour with respect to gap-detection seasonal timing and seed carry-over across years in alpine grassland forbs. We found that gap-detecting germination responses occurred in the majority of relatively small-seeded species and could be well predicted from the species' light and temperature responses in the lab. Larger-seeded species had no such responses and emerged in all microsites in the field. Several large-seeded species suffered high seedling mortality in high-competition microsites, reflecting the costs of a broad regeneration niche. Seasonal timing of seedling emergence was weak, and not well predicted by germination responses. All species showed considerable seed carry-over across years, but this could only to a limited degree be related to germination responses in the lab, suggesting that the temporal storage may be environmentally enforced rather than dormancy-driven in this system.

\section{ACKNOWLEDGEMENTS}

The authors thank the staff at the Centre for Plant Research in Controlled Climate at the Agricultural University of Norway for laboratory assistance and advice, K. T. Hansen and H. Solstad for field and laboratory assistance, E. Fremstad for advice and help on seed collection, the. Eggen family for allowing us to set up the field experiment on their land, I. Heuch and E. Heegaard for statistical advice, B. Helle for assistance with the figures, and H. J. B. Birks, J.-A. Grytnes, S. Peglar, V. Vange, and three anonymous reviewers for comments on earlier versions of this manuscript. The work was supported by the Norwegian Research Council [Grant no. 73758/410] and A. Heiberg and H. B. Fasmers Fond at the University of Bergen. 
Vandvik et al., - Recruitment-regulating mechanisms in subalpine grassland

\section{LITERATURE CITED}

Andersson, L., and Milberg, P. 1998. Variation in seed dormancy among mother plants, population, and year of seed collection. Seed Sci. Res. 8: 29-38.

Angevine, M.W., and Chabot, B.F. 1979. Seed germination syndromes in higher plants. In Topics in Plant Population Biology. Edited by O.T. Solbrig, S. Jain, G.B. Johnson, and P.H Raven. Columbia University Press, New York, NY. pp. 188-206.

Austrheim, G., and Eriksson, O. 2001. Plant species diversity and grazing in the Scandinavian mountains - patterns and processes at different spatial scales. Ecography 24: 683-695.

Austrheim, G., and Eriksson, O. 2003. Recruitment and life-history traits of sparse plant species in subalpine grasslands. Can. J. Bot. 81: 171-182.

Bates, D., Maechler, M., Bolker, B., and Walker S. 2014._lme4: Linear mixed-effects models using Eigen and S4_. R package version 1.1-7. Available from: http://CRAN.R-project.org/package=lme4

Baskin, C.C., and Baskin, J.M. 2004. A classification system for seed dormancy. Seed Sci. Res. 14: 1-16.

Baskin, C.C., and Baskin, J.M. 2014. Seeds. Ecology, Biogeography, and Evolution of Dormancy and Germination. 2nd edn. Elsivier, San Diego, CA.

Battla, B.C., Kruk, C., and Benech-Arnold, R.L. 2001. Very early detection of canopy presence by seeds through perception of subtle modifications in red: far-red signals. Funct. Ecol. 14: 195-200.

Bell, D.T., King, L.A., and Plummer, J.A. 1999. Ecophysiological effects of light quality and nitrate on seed germination in species from Western Australia. Austr. J. Ecol. 24: 210. 
Vandvik et al., - Recruitment-regulating mechanisms in subalpine grassland

Bell, D.T., Rokich, D.P., McChesney, C.J,. and Plummer, J.A. 1995. Effects of temperature, light, and gibberellic acid on the germination of seeds of 43 species native to Western Australia. J. Veg. Sci. 6: 797-806.

Bueno, C.G., Reine, R., Alados, C.L., and Gomez-Garcia, D. 2011. Effects of large wild boar disturbances on alpine soil seed banks. Bas. Appl. Ecol. 12: 125-133.

Bullock, J.M. 2000. Gaps and Seedling Colonization. In Seeds - The ecology of regeneration in plant communities. Edited by M. Fenner. CAB International, Wallingford, UK. pp. 375-396.

Cavieres, L.A., and Arroyo, M.T. 2000. Seed germination response to cold stratification period and thermal regime in Phacelia secunda (Hydrophyllaceae). Plant Ecol. 149: 1-8.

Chambers, J.C., MacMahon, J.A., and Brown, R.W. 1990. Alpine seedling establishment: the influence of disturbance type. Ecology 71: 1323-1341.

Chambers, J.C. 1995. Relationship between seed fates and seedling establishment in alpine ecosystems. Ecology 76: 2124-2133.

Donohue, K., de Casas, R.R., Burghardt, L., Kovach, K., and Wills, C.G. 2010. Germination, Postgermination Adaptation, and Species Ecological Ranges. Ann. Rev. Ecol. Evol. Syst. 41: 293-319.

Donohue, K. 2005. Seeds and seasons: interpreting germination timing in the field. Seed Sci. Res. 15: 175-187.

Fenner, M. 2000. (Editor). Seeds: the ecology of regeneration in plant communities. CAB International, Wallingford, UK.

Forbis, T,A. 2003. Seedling demography in an alpine ecosystem. American Journal of Botany 90: 1197-1206. 
Vandvik et al., - Recruitment-regulating mechanisms in subalpine grassland

Fox, J., and Weisberg, S. 2011. An $\{$ R $\}$ Companion to Applied Regression, Second Edn..

Sage, Thousand Oaks, CA. Available from:

http://socserv.socsci.mcmaster.ca/jfox/Books/Companion

Graae, B.J., Ejrnaes, R., Lang, S.I., Meineri, E., Ibarra, P.T., and Bruun, H.H., 2011. Strong microsite control of seedling recruitment in tundra. Oecologia 166: 565-576

Gremer, J.R., and Venable, D.L. 2014. Bet hedging in desert winter annual plants: optimal germination strategies in a variable environment. Ecol. Lett. 17:380-387.

Grime, J.P., Mason, G., Curtis, A.V., Rodman, J., and Band, S.R. 1981. A comparative study of germination characteristics in a local flora. J. Ecol. 69: 1017-1059. doi: $10.2307 / 2259651$

Grubb, P.J. 1988. The uncoupling of disturbance and recruitment, two kinds of seed bank, and persistence of plant populations at the regional and local scales. Ann. Zool. Fenn. 25: $23-36$.

Hilton, J.R. 1984. The influence of light and potassium nitrate on the dormancy and germination of Avena fatua (L.) (wild oat) seed and its ecological significance. New Phyt. 96: 31-34.

Hubbell, S.P., Foster, R.B., O’Brien, S.T., Harms, K.E., Condit, R., Wechsler, B., Wright, S. J., and Loo de Lao, S.. 1999. Light-cap disturbances, recruitment limitation, and tree diversity in a neotropical forest. Science 283: 554-557.

doi:10.1126/science. 283.5401 .554

Hoyle, G.L., Venn, S.E., Steadman, K.J., Good, R.B., Mcauliffe, E.J., Williams, E.R., and Nicotra, A.B. 2013. Soil warming increases plant species richness but decreases germination from the alpine soil seed bank. Glob. Change Biol. 19: 1549-1561. doi:10.1111/gcb.12135 
Vandvik et al., - Recruitment-regulating mechanisms in subalpine grassland

Körner, C. 1999. Alpine Plant Life. Functional Plant Ecology of High Mountain Ecosystems. Springer-Verlag, Berlin Heidelberg, Germany.

Kotorová, I., and Lepš, J. 1999. Comparative ecology of seedling recruitment in an oligotrophic wet meadow. J. Veg. Sci. 10: 175-186.

Leishman, M.R., Wright, I.J., Moles, A.T., and Westoby, M. 2000. The evolutionary ecology of seed size. In. Seeds - The ecology of regeneration in plant communities. Edited by M. Fenner. CAB International, Wallingford, UK. pp. 31-57.

Lid, J., and Lid, D.T. 2005. Norsk flora. Ed. by R. Elven. Det norske samlaget, Oslo.

Mack, R.N., and Pyke, D.A. 1984. The demography of Bromus tectorum - the role of microclimate, grazing, and disease. J. Ecol. 72: 731-748.

Masuda, M., and Washitani, I. 1990. A comparative ecology of the seasonal schedules for 'reproduction by seeds' in a moist tall grassland community. Funct. Ecol. 4: 169182.

McGraw, J.B., and Vaverek, M.C. 1989. The role of buried viable seeds in arctic and alpine plant communities. In Ecology of Soil Seed Banks. Edited by M.A. Leck, V.T. Parker, and R.L. Simpson. Academic Press, San Diego, CA. pp. 91-105.

Meyer, S.E., and Monsen, S.B. 1991. Habitat-correlated variation in mountain big sagebrush (Artemisia tridentata ssp. vaseyana) seed germination patterns. Ecology 72: 739742.

Milbau, A., Shevtsova, A., Osler, N., Mooshammer, M., and Graae, B.J. 2013. Plant community type and small-scale disturbances, but not altitude, influence the invasibility in subarctic ecosystems. New Phyt. 197: 1002-1011.

Milberg, P. 1997. Weed seed germination after a short-term light exposure: germination rate, photon fluence response and interaction with nitrate. Weed Res. 37: 157-164. 
Vandvik et al., - Recruitment-regulating mechanisms in subalpine grassland

Milberg, P., Hallgren, E., and Palmer, M.W. 2001. Timing of disturbance and vegetation development: how sowing date affects the weed flora in spring-sown crops. J. Veg. Sci. 12: 93-98.

Mondoni, A., Pedrini, S., Bernareggi, G., Abeli, T., Probert, R.J., Ghitti, M., and Orsenigo, S. 2015. Climate warming could increase recruitment success in glacier foreland plants. Ann. Bot. 116: 907-916.

Muller, E., Cooper, EJ., and Alsos, IG. 2011. Germinability of arctic plants high in perceived optimal conditions but low in the field. Botany 89:337-348.

Murdoch, A.J., and Ellis, R.H. 2000. Dormancy, Viability, and Longevity. In Seeds - The ecology of regeneration in plant communities. Edited by M. Fenner. CAB International, Wallingford, UK. pp. 183-214.

Olff, H., Pegtel, D.M., van Groendael, J.M., and Bakker, J.P. 1994. Germination strategies during grassland succession. J. Ecol. 82: 69-77.

Philippi, T. 1993. Bet-hedging germination of desert annuals: beyond the first year. Am. Nat. 142: $474-487$.

R Core Team 2014. R: A language and environment for statistical computing. R Foundation for Statistical Computing, Vienna, Austria. Available from: http://www.Rproject.org/

Reader, R., and Buck, J. 1990. Control of seedling density on disturbed ground: role of seedling establishment for some mid-successional, old-field species. Can. J. Bot. 69: $773-777$.

Rice, K.J. 1985. Responses of Erodium to varying microsites: the role of germination cueing. Ecology 66: 1651-1657.

Roach, D.A., and Wulff, R.D. 1987. Maternal effects in plants. Ann. Rev. Ecol. Syst. 18: $209-235$. 
Vandvik et al., - Recruitment-regulating mechanisms in subalpine grassland

Ryser, P. 1993. Influences of neighboring plants on seedling establishment in limestone grassland. J. Veg. Sci. 4: 195-202.

Schütz, W., and Milberg, P. 1997. Seed dormancy in Carex canescens: regional differences and ecological consequences. Oikos 78: 420-428.

Schütz, W. 1999. Germination responses of temperate Carex-species to diurnally fluctuating temperatures - a comparative study. Flora 194: 21-32.

Spindelböck J.P., Cook Z., Daws M.I., Heegaard E., Måren I.E., and Vandvik V. 2013. Conditional cold avoidance drives variation in germination behaviour in Calluna vulgaris. Ann. Bot. 112: 801-810.

Thompson, K., and Grime, J.P. 1979. Seasonal variation in the seed bank of herbaceous species in ten contrasting habitats. J. Ecol. 67: 893-921.

Vandvik, V., and Birks, H,J.B. 2002. Pattern and process in Norwegian upland grasslands a functional analysis. J. Veg. Sci. 13: 123-134.

Vandvik, V., Elven, R., and Töpper, J. 2016. Data from: “Seedling recruitment in subalpine grassland forbs: Predicting field regeneration behaviour from lab germination responses”. Dryad Digital Repository doi:10.5061/dryad.04f8c.

Vandvik, V., and Goldberg, D.E. 2006. Sources of diversity in a grassland metacommunity: quantifying the contribution of dispersal to species richness. Am. Nat. 168: 157-167.

Vandvik, V. 2004. Gap dynamics in perennial subalpine grasslands: trends and processes change during secondary succession. J. Ecol. 92: 86-96.

Venable, D.L., and Brown, J.S. 1988. The selective interactions of dispersal, dormancy, and seed size as adaptations for reducing risk in variable environments. Am. Nat. 131:360-384.

Vleeshouwers, L.M., Bouwmeester, H.J., and Karssen, C.M. 1995. Redefining seed dormancy: an attempt to integrate physiology and ecology. J. Ecol. 83: 1031-1037. 
Vandvik et al., - Recruitment-regulating mechanisms in subalpine grassland

Vranckx, G., and Vandelook F. 2012. A season- and gap-detection mechanism regulates seed germination of two temperate forest pioneers. Plant Biol. 14: 481-490.

Wagmann K., Hautekèete N-C., Piquot Y., Meunier C., Schmitt S.E., and Van Dijk H. 2012. Seed dormancy distribution: explanatory ecological factors. Ann. Bot. 110: 12051219

Washitani, I., and Masuda, M. 1990. A comparative study of the germination characteristics of seeds from a moist tall grassland community. Funct. Ecol. 4: 543- 557.

Willis C.G., Baskin C.C., Baskin J.M., Auld J.R., Venable D.L., Cavender-Bares J., Donohue K., Rubio de Casas R., and The NESCent Germination Working Group 2014. The evolution of seed dormancy: environmental cues, evolutionary hubs, and diversification of the seed plants. New Phyt. 203: 300-309. 
Vandvik et al., - Recruitment-regulating mechanisms in subalpine grassland

1 Table 1. Taxonomic, morphological, life-history, distributional, and ecological characteristics of the 11 target species.

\begin{tabular}{|c|c|c|c|c|c|c|c|c|c|c|c|}
\hline Species & Family & $\begin{array}{c}\text { Seed mass* } \\
(\mathrm{mg})\end{array}$ & $\begin{array}{c}\text { Seed dormancy } \\
\text { class } \dagger\end{array}$ & $\begin{array}{c}\text { Plant height } \\
(\mathrm{cm})\end{array}$ & Life-history & Altitudinal limit & $\begin{array}{c}\text { Geographical } \\
\text { distribution }\end{array}$ & $\begin{array}{c}\text { Regional } \\
\text { abundance }\end{array}$ & $\begin{array}{c}\text { Habitat } \\
\text { selectivity }\end{array}$ & $\begin{array}{l}\text { Bedrock } \\
\text { requirement }\end{array}$ & $\begin{array}{l}\text { Soil fertility } \\
\text { requirement }\end{array}$ \\
\hline Campanula rotundifolia & Campanulaceae & 0.06 & MPD & $10-50$ & Perennial & 1920 & Ubiquitous & Common & Wide & Indifferent & Low \\
\hline Gentianella amarella & Gentianaceae & 0.13 & MPD* & $5-25$ & Biennial & 1290 & Lowland & Common & Grassland & Basic & Low \\
\hline Gentiana nivalis & Gentianaceae & 0.18 & MPD & $3-20$ & Annual/Biennial & 1880 & Alpine & Scattered & Grassland & Basic & Low \\
\hline Geranium sylvaticum & Geraniaceae & 4.71 & PY & $20-80$ & Perennial & 1750 & Ubiquitous & Common & Wide & Indifferent & High \\
\hline Knautia arvensis & Caprifoliaceae & 6.14 & PD & $30-80$ & Perennial & 1220 & Lowland & Common & Grassland & Indifferent & High \\
\hline Potentilla crantzii & Rosaceae & 0.42 & $\mathrm{PD} \ddagger$ & $5-25$ & Perennial & 1920 & Ubiquitous & Common & Grassland & Basic & Low \\
\hline Primula scandinavica & Primuaceae & 0.06 & PD,ND $\ddagger$ & $5-15$ & Perennial & 1560 & Ubiquitous & Scattered & Grassland & Basic & Low \\
\hline Ranunculus platanifolius & Ranunculaceae & 4.29 & MPD $\ddagger$ & $50-150$ & Perennial & 1390 & Alpine & Scattered & Wide & Indifferent & High \\
\hline Trollius europaeus & Ranunculaceae & 0.40 & MPD & $20-80$ & Perennial & 1300 & Ubiquitous & Common & Wide & Indifferent & High \\
\hline Veronica alpina & Plantaginaceae & 0.05 & PD & $5-15$ & Perennial & 1920 & Alpine & Scattered & Grassland & Indifferent & Low \\
\hline Viola biflora & Violaceae & 0.76 & PD & $5-15$ & Perennial & 1500 & Alpine & Common & Wide & Basic & Low \\
\hline
\end{tabular}

$4 \quad$ *Seed mass is calculated as the mean of 60 - 300 seeds (depending on seed size) weighed in three batches. $\dagger$ Seed dormancy class: physical [PY],

5 physiological [PD], morphophysiological [MPD], no known dormancy [ND] from Baskin and Baskin, 2014. ¥Not reported in Baskin and Baskin, 2014,

6 dormancy type(s) inferred from related taxa. All other data are compiled from Lid and Lid (2005) and refer to the species' ecological characteristics within

7 Norway. 
Vandvik et al., - Recruitment-regulating mechanisms in subalpine grassland

Table 2. Germination onset and rate responses to the fixed-effects variables (A) temperature and light, (B) diurnally fluctuating temperatures,

(C) moist chilling, and (D). dormancy breaking by means of gibberellic acid in the lab experiment for 10 perennial grassland forbs.

\begin{tabular}{|c|c|c|c|c|c|c|c|c|c|c|c|c|c|c|c|c|c|c|c|c|c|c|}
\hline \multicolumn{2}{|c|}{ Experiment and effects } & \multirow[b]{2}{*}{$\mathrm{df}$} & \multicolumn{2}{|c|}{$\begin{array}{l}\text { Campanula } \\
\text { rotundifolia }\end{array}$} & \multicolumn{2}{|c|}{$\begin{array}{c}\text { Gentiana } \\
\text { nivalis }\end{array}$} & \multicolumn{2}{|c|}{$\begin{array}{l}\text { Gentianella } \\
\text { amarella }\end{array}$} & \multicolumn{2}{|c|}{$\begin{array}{l}\text { Geranium } \\
\text { sylvaticum }\end{array}$} & \multicolumn{2}{|c|}{$\begin{array}{l}\text { Knautia } \\
\text { arvensis }\end{array}$} & \multicolumn{2}{|c|}{$\begin{array}{c}\text { Potentilla } \\
\text { crantzii }\end{array}$} & \multicolumn{2}{|c|}{$\begin{array}{c}\text { Primula } \\
\text { scandinavica }\end{array}$} & \multicolumn{2}{|c|}{$\begin{array}{l}\text { Trollius } \\
\text { europaeus }\end{array}$} & \multicolumn{2}{|c|}{$\begin{array}{l}\text { Veronica } \\
\text { alpina }\end{array}$} & \multicolumn{2}{|c|}{$\begin{array}{l}\text { Viola } \\
\text { biflora }\end{array}$} \\
\hline & & & $x^{2}$ & $p$-value & $x^{2}$ & $p$-value & $x^{2}$ & $p$-value & $x^{2}$ & $\mathrm{p}$-value & $x^{2}$ & $\mathrm{p}$-value & $x^{2}$ & $\mathrm{p}$-value & $x^{2}$ & $\mathrm{p}$-value & $\chi^{2}$ & $\mathrm{p}$-value & $x^{2}$ & $\mathrm{p}$-value & $x^{2}$ & $p$-value \\
\hline \multirow[t]{7}{*}{ (A) } & Temperature & 3 & 23.9 & $<0,0001$ & - & - & - & - & 11.8 & 0.0082 & 33.9 & $<0,0001$ & 8.5 & 0.0370 & 85.2 & $<0,0001$ & - & - & 107.6 & $<0,0001$ & & \\
\hline & Light & 1 & 8.3 & 0.0039 & - & - & - & - & & & 36.1 & $<0,0001$ & 20.7 & $<0,0001$ & 65.1 & $<0,0001$ & - & - & 14.8 & 0.0001 & & \\
\hline & Temperature $\mathrm{x}$ Light & 3 & & & - & - & - & - & & & 6.9 & 0.0765 & & & & & - & - & & & & \\
\hline & Time & 6 & 209.5 & $<0,0001$ & - & - & - & - & 131.6 & $<0,0001$ & 166.6 & $<0,0001$ & 142.8 & $<0,0001$ & 103.7 & $<0,0001$ & - & - & 163.1 & $<0,0001$ & 89.9 & $<0,0001$ \\
\hline & Temperature $\mathrm{x}$ Time & 18 & 9.4 & 0.0249 & - & - & - & - & & & & & & & & & - & - & 7.3 & 0.0634 & & \\
\hline & Light $x$ Time & 6 & 17.3 & $<0,0001$ & - & - & - & - & & & 10.7 & 0.0011 & & & 17.7 & $<0,0001$ & - & - & & & & \\
\hline & Temperature $x$ Light $x$ Time & 18 & & & - & - & - & - & & & & & & & & & - & - & & & & \\
\hline \multirow[t]{7}{*}{ (B) } & Fluctuation & 1 & 1.3 & 0.2528 & - & - & - & - & & & & & 3.7 & 0.0539 & 4.4 & 0.0352 & - & - & & & & \\
\hline & Light & 1 & 5.4 & 0.0200 & - & - & - & - & & & 8.5 & 0.0035 & 22.9 & $<0.0001$ & 25.6 & $<0.0001$ & - & - & 15.5 & $<0.0001$ & & \\
\hline & Fluctuation $\mathrm{x}$ Light & 1 & & & - & - & - & - & & & & & 4.3 & 0.0384 & 8.7 & 0.0031 & - & - & & & & \\
\hline & Time & 6 & 130.8 & $<0.0001$ & - & - & - & - & 65.2 & $<0.0001$ & 87.3 & $<0.0001$ & 91.5 & $<0.0001$ & 105.0 & $<0.0001$ & - & - & 95.7 & $<0.0001$ & 46.1 & $<0.0001$ \\
\hline & Fluctuation $\mathrm{x}$ Time & 6 & 4.2 & 0.0415 & - & - & - & - & & & & & & & 3.9 & 0.0473 & - & - & & & & \\
\hline & Light $x$ Time & 6 & 19.5 & $<0.0001$ & - & - & - & - & & & 17.1 & $<0.0001$ & & & 18.4 & $<0.0001$ & - & - & & & & \\
\hline & Fluctuation $\times$ Light $\times$ Time & 6 & & & & & & & & & & & & & 3.4 & 0.0639 & & & & & & \\
\hline \multirow[t]{7}{*}{ (C) } & Moist chilling & 1 & & & - & - & - & - & 8.4 & 0.0038 & 5.2 & 0.0223 & 8.2 & 0.0041 & 32.6 & $<0.0001$ & - & - & 11.8 & 0.0006 & 33.3 & $<0.0001$ \\
\hline & Light & 1 & 6.3 & 0.0122 & - & - & - & - & & & 4.9 & 0.0272 & 47.4 & $<0.0001$ & 13.7 & 0.0002 & - & - & 9.3 & 0.0023 & 6.5 & 0.0109 \\
\hline & Moist chilling $\mathrm{x}$ Light & 1 & & & - & - & - & - & & & 5.2 & 0.0227 & & & & & - & - & & & & \\
\hline & Time & 6 & 40.5 & $<0.0001$ & - & - & - & - & 60.9 & $<0.0001$ & 33.7 & $<0.0001$ & 69.9 & $<0.0001$ & 52.0 & $<0.0001$ & - & - & 53.6 & $<0.0001$ & 30.8 & $<0.0001$ \\
\hline & Moist chilling $x$ Time & 6 & & & - & - & - & - & 4.5 & 0.0337 & 4.1 & 0.0434 & 4.0 & 0.0462 & 10.2 & 0.0014 & - & - & & & & \\
\hline & Light $x$ Time & 1 & 2.9 & 0.0865 & - & - & - & - & & & & & & & 19.8 & $<0.0001$ & - & - & & & 2.9 & 0.0900 \\
\hline & Moist chilling $\mathrm{x}$ Light $\mathrm{x}$ Time & 6 & & & - & - & - & - & & & & & & & & & - & - & & & & \\
\hline \multirow[t]{3}{*}{ (D) } & Gibberillic acid & 1 & 3.6 & 0.0573 & 31.7 & $<0.0001$ & 8.2 & 0.0041 & 0.5 & 0.4957 & & & 3.0 & 0.0809 & & & 51.5 & $<0.0001$ & 58.7 & $<0.0001$ & 28.7 & $<0.0001$ \\
\hline & Time & 6 & 43.7 & $<0.0001$ & 21.2 & $<0.0001$ & 34.8 & $<0.0001$ & 49.5 & $<0.0001$ & 64.5 & $<0.0001$ & 49.1 & $<0.0001$ & 35.0 & 0.0005 & 38.4 & $<0.0001$ & 38.7 & $<0.0001$ & 20.1 & $<0.0001$ \\
\hline & Gibberillic acid x Time & 6 & & & 16.2 & $<0.0001$ & 14.5 & 0.0001 & 16.0 & $<0.0001$ & & & 8.1 & 0.0044 & & & 18.7 & $<0.0001$ & & & 4.3 & 0.0381 \\
\hline
\end{tabular}


Vandvik et al., - Recruitment-regulating mechanisms in subalpine grassland

Note: One species, Ranunculus plantanifolius, had very low germination $(0.05 \%)$ and is therefore not included. For the remaining species, only results from experiments yielding germination $>5 \%$ are presented (species and experiments not tested are denoted with - in each case). Entries are Wald II $\chi^{2}$ values and the associated p-values of the final models of generalized linear mixed effects models. Variables in italics are non-focus variables; for example time, which simply reflects that germination of seed batches accumulate through time. Similarly, the effect of $\underline{\text { light }}$ and $\underline{\text { light } x \text { time }}$ are non-focus variables in experiment (B). Total df $=112$ (A) and 28 (B, C, D) per species and experiment.- not tested due to low germination rate in this experiment. 
Vandvik et al., - Recruitment-regulating mechanisms in subalpine grassland

Table 3. Final germination proportion responses to the fixed-effect variables (A) temperature and light, (B) diurnally fluctuating temperatures,

(C) moist chilling, and (D) dormancy breaking by means of gibberellic acid in lab experiments for 10 perennial grassland forbs. Only statistically significant model terms after model selection are shown.

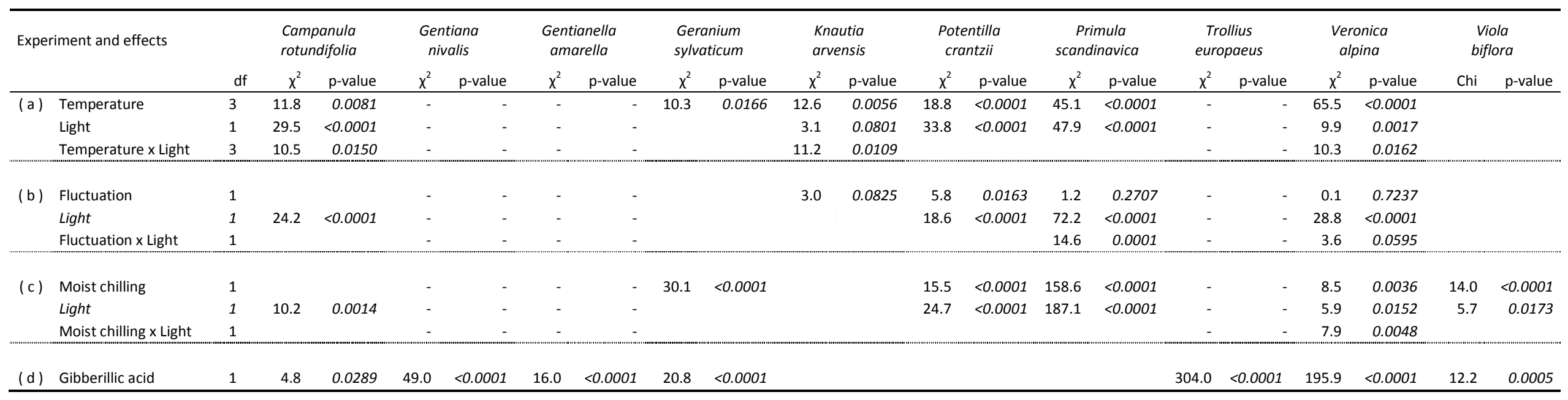

Note: One species, Ranunculus plantanifolius, had very low germination rate $(0.05 \%)$ and is therefore not included. For the remaining species, only results from experiments yielding germination $>5 \%$ are presented (species and experiments not tested are denoted with - in each case). Entries are Wald II Chisquare values and the associated p-values of the final models of generalized linear models. Variables in italics are non-focus variables; for example light and in experiment (B). Total $\mathrm{df}=112(\mathrm{~A})$ and $28(\mathrm{~b}, \mathrm{c}, \mathrm{d})$ per species and experiment. 
Vandvik et al., - Recruitment-regulating mechanisms in subalpine grassland 
Vandvik et al., - Recruitment-regulating mechanisms in subalpine grassland

Table 4. Seedling emergence and mortality in the field experiment for 11 perennial grassland forbs. The average \% seedling recruitment per species, the proportion of these seedlings that emerged, and the proportions of the emerged seedlings that died under different treatments and between censuses in the field.

\begin{tabular}{|c|c|c|c|c|c|c|c|c|c|c|c|c|c|c|}
\hline \multirow[b]{2}{*}{ Species / Treatment } & \multicolumn{8}{|c|}{ Seedling emergence } & \multicolumn{6}{|c|}{ Seedling mortality } \\
\hline & Average & Control & Cut $5 \mathrm{~cm}$ & Cut $0 \mathrm{~cm}$ & Gap & $\begin{array}{l}\text { Autumn } \\
1999\end{array}$ & $\begin{array}{l}\text { Spring } \\
2000\end{array}$ & $\begin{array}{l}\text { Autumn } \\
2000\end{array}$ & Control & Cut $5 \mathrm{~cm}$ & Cut $0 \mathrm{~cm}$ & Gap & Winter & Summer \\
\hline Campanula rotundifolia & 4.60 & $0.09^{\mathrm{a}}$ & $0.05^{\mathrm{a}}$ & $0.03^{\mathrm{a}}$ & $0.82^{\mathrm{b}}$ & 0.60 & 0.08 & 0.32 & $0.50^{\mathrm{a}}$ & $0.60^{\mathrm{a}}$ & $0.00^{\mathrm{b}}$ & $0.21^{\mathrm{b}}$ & 0.31 & 0.13 \\
\hline Gentianella amarella & 2.10 & $0.07^{\mathrm{a}}$ & $0.10^{\mathrm{a}}$ & $0.05^{\mathrm{a}}$ & $0.79^{b}$ & $0.38^{\mathrm{a}}$ & $0.00^{b}$ & $0.62^{\mathrm{a}}$ & - & - & 0.50 & 0.15 & 0.00 & 0.38 \\
\hline Gentiana nivalis & 0.20 & 0.00 & 0.00 & 0.50 & 0.50 & 0.50 & 0.50 & 0.00 & - & - & 1.00 & 1.00 & 1.00 & - \\
\hline Geranium sylvaticum & 11.50 & 0.20 & 0.30 & 0.29 & 0.22 & 0.51 & 0.24 & 0.25 & $0.37^{\mathrm{a}}$ & $0.29^{a}$ & $0.18^{b}$ & $0.2^{\mathrm{b}}$ & $0.34^{\mathrm{a}}$ & $0.14^{b}$ \\
\hline Knautia arvensis & 3.70 & 0.18 & 0.27 & 0.30 & 0.25 & 0.30 & 0.26 & 0.44 & 0.23 & 0.15 & 0.27 & 0.28 & 0.45 & 0.23 \\
\hline Potentilla crantzii & 2.70 & $0.02^{\mathrm{a}}$ & $0.15^{\mathrm{ab}}$ & $0.30^{\mathrm{ab}}$ & $0.53^{b}$ & $0.26^{\mathrm{a}}$ & $0.19^{\mathrm{a}}$ & $0.55^{\mathrm{b}}$ & 0.00 & 0.38 & 0.13 & 0.29 & 0.57 & 0.31 \\
\hline Primula scandinavica & 0.10 & 0.00 & 0.00 & 1.00 & 0.00 & 1.00 & 0.00 & 0.00 & - & - & 1.00 & - & 1.00 & - \\
\hline Ranunculus platanifolius & 8.80 & $0.25^{\mathrm{a}}$ & $0.20^{\mathrm{a}}$ & $0.20^{\mathrm{a}}$ & $0.35^{b}$ & $0.11^{\mathrm{b}}$ & $0.67^{\mathrm{a}}$ & $0.22^{\mathrm{ab}}$ & $0.62^{\mathrm{a}}$ & $0.26^{\mathrm{b}}$ & $0.57^{\mathrm{a}}$ & $0.24^{\mathrm{b}}$ & $0.79^{\mathrm{a}}$ & $0.39^{b}$ \\
\hline Trollius europaeus & 4.70 & $0.28^{\mathrm{b}}$ & $0.15^{\mathrm{b}}$ & $0.11^{\mathrm{b}}$ & $0.47^{\mathrm{a}}$ & $0.19^{b}$ & $0.38^{\mathrm{a}}$ & $0.43^{\mathrm{a}}$ & 0.00 & 0.00 & 0.10 & 0.07 & 0.22 & 0.00 \\
\hline Veronica alpina & 1.40 & $0.04^{\mathrm{a}}$ & $0.04^{\mathrm{a}}$ & $0.00^{\mathrm{a}}$ & $0.93^{\mathrm{b}}$ & $0.07^{\mathrm{a}}$ & $0.44^{\mathrm{b}}$ & $0.48^{\mathrm{b}}$ & 0.00 & 0.00 & - & 0.04 & 0.00 & 0.07 \\
\hline Viola biflora & 14.10 & $0.36^{\mathrm{a}}$ & $0.22^{\mathrm{a}}$ & $0.18^{\mathrm{b}}$ & $0.24^{\mathrm{a}}$ & 0.30 & 0.36 & 0.34 & $0.24^{\mathrm{a}}$ & $0.25^{\mathrm{a}}$ & $0.00^{\mathrm{b}}$ & $0.22^{\mathrm{ab}}$ & 0.25 & 0.21 \\
\hline Seed mass correlation & $0.62 *$ & $0.54 *$ & $0.89 * * *$ & 0.39 & $-0.60^{*}$ & -0.13 & 0.23 & -0.08 & -0.32 & -0.26 & 0.01 & -0.45 & -0.32 & -0.42 \\
\hline
\end{tabular}

Note: Within species, response variables (emergence vs. mortality) and groups of columns (microsite vs.time), significant differences are denoted by

different superscripts $\left({ }^{a},{ }^{b}\right)$. Microsite treatments are uncut controls with a standing vegetation of $\mathrm{ca} .20 \mathrm{~cm}$, plots with vegetation cut at $5 \mathrm{~cm}$ and at $0 \mathrm{~cm}$, and bare-ground gaps with all above- and below-ground plant parts removed. Winter mortality is between autumn 1999 and spring 2000, summer mortality is between spring 2000 and autumn 2000. Seed mass correlation is the Spearman rank correlation between the different response variables and seed mass (see Table 1), where $*=\mathrm{P}<0.05, * *=\mathrm{P}<0.01, * * *=\mathrm{P}<0.005$. Total $\mathrm{df}=64$ per species and response variable (germination, mortality).Entries are means of five replicates. 
Vandvik et al., - Recruitment-regulating mechanisms in subalpine grassland

Table 5. Linking lab germination responses to field recruitment. Summary of the predicted (italics) and observed seedling emergence regeneration in response to different microsites (bare-ground gaps, vegetation cut at $0 \mathrm{~cm}$ above ground (C0), vegetation cut at $5 \mathrm{~cm}(\mathrm{C} 5)$ and uncut controls with a grassland sward of ca. $20 \mathrm{~cm}$ ), seasons (spring, autumn, indifferent), and seed carryover across years (low, intermediate, and high) for 11 subalpine grassland forbs.

\begin{tabular}{|c|c|c|c|c|c|c|c|c|c|}
\hline \multirow[t]{2}{*}{ Species } & \multirow[b]{2}{*}{$\begin{array}{l}\text { Seed mass } \\
(\mathrm{mg})\end{array}$} & \multicolumn{3}{|c|}{ Microsite selectivity } & \multicolumn{3}{|c|}{ Temporal cueing } & \multicolumn{2}{|c|}{ Seed carry-over } \\
\hline & & $\begin{array}{l}\text { Predicted from } \\
\text { lab experiments }\end{array}$ & $\begin{array}{c}\begin{array}{c}\text { Observed field } \\
\text { emergence }\end{array} \\
\end{array}$ & $\begin{array}{c}\text { Observed field } \\
\text { mortality }\end{array}$ & $\begin{array}{l}\text { Predicted from } \\
\text { lab experiments }\end{array}$ & $\begin{array}{c}\begin{array}{c}\text { Observed field } \\
\text { emergence }\end{array} \\
\end{array}$ & $\begin{array}{c}\text { Observed field } \\
\text { mortality }\end{array}$ & $\begin{array}{l}\text { Predicted from } \\
\text { lab experiments }\end{array}$ & $\begin{array}{c}\text { Observed field } \\
\text { emergence }\end{array}$ \\
\hline Campanula rotundifolia & 0.06 & $G a p^{L, F, T}$ & Gap & Control, C5 & Autumn $^{-c}$ & Autumn & Indifferent & Low $^{5}$ & Low \\
\hline Gentianella amarella & 0.13 & Unknown ${ }^{G}$ & Gap & na & Unknown ${ }^{G}$ & Autumn & Indifferent & $\operatorname{High}^{G, S}$ & Intermediate \\
\hline Gentiana nivalis & 0.18 & Unknown ${ }^{G}$ & (Gap) & na & Unknown ${ }^{G}$ & na & na & $\operatorname{High}^{G, S}$ & na \\
\hline Geranium sylvaticum & 4.71 & Indifferent & Indifferent & Control, C5 & Autumn $n^{-c}$ & Indifferent & Winter & Low & Intermediate \\
\hline Knautia arvensis & 6.14 & Indifferent & Indifferent & Indifferent & Spring $^{c}$ & Indifferent & Indifferent & Intermediate $^{G, S}$ & Intermediate \\
\hline Potentilla crantzii & 0.42 & $G a p^{L, T, F}$ & Gap, CO, C5 & Indifferent & Autumn ${ }^{-c}$ & 1999 & Indifferent & Low & Low \\
\hline Primula scandinavica & 0.06 & $\operatorname{Gap}^{L, T, F}$ & (Gap) & na & Spring ${ }^{C, T}$ & na & na & Intermediate $^{G, S}$ & na \\
\hline Ranunculus platanifolius & 4.29 & $n a$ & Gap & Control, CO & na & Spring & Winter & $n a$ & High \\
\hline Trollius europaeus & 0.40 & Unknown ${ }^{G}$ & Gap & Indifferent & Unknown ${ }^{G}$ & 2000 & Indifferent & $\operatorname{High}^{G, S}$ & High \\
\hline Veronica alpina & 0.05 & $G a p^{L, T}$ & Gap & Indifferent & Spring ${ }^{c, T}$ & Indifferent & Indifferent & Low & Intermediate \\
\hline Viola biflora & 0.76 & Indifferent & Gap, C0, C5 & UC, C5 & Spring ${ }^{C, T}$ & Indifferent & Indifferent & Low & High \\
\hline
\end{tabular}

Note: Superscripts denote the specific responses in the lab germination experiments from which these predictions are derived (see text for details): Light ${ }^{\mathrm{L}}$,

Temperature $^{\mathrm{T}}$, Flutuating temperature ${ }^{\mathrm{F}}$, Moist chilling ${ }^{\mathrm{C}}$, Gibberillic $\operatorname{acid}^{\mathrm{G}}$.Slow or low germination ${ }^{\mathrm{S}}$. Unless preceded by a negative sign, these superscripts denote positive germination responses in the treated seeds relative to the controls (light vs. darkness, high temperature vs. low, fluctuating temperature vs. constant, moist chilled vs. non-chilled, $\mathrm{GA}_{3}$ vs. water). Seed mass data provided to aid interpreatation. na = not available because the species did not germinate (lab) or emerge (field) under the relevant treatments. 
Vandvik et al., - Recruitment-regulating mechanisms in subalpine grassland

Figure 1. Observed germination in response to light and temperature on germination during the 32-day lab experiment for seven subalpine grassland forbs. Four additional species were tested (Comsastoma tenellum, Gentianella amarella, Trollius europaeus, and Ranunculus platanifolius) but these had germination $<5 \%$ under all treatments and are not presented. For each combination of species $\mathrm{x}$ light $\mathrm{x}$ temperature $\mathrm{x}$ census time, the mean percent germination in four replicate dishes $\pm 1 \mathrm{SD}$ is shown. Fluctuating $\left(25 / 10^{\circ} \mathrm{C}\right)$ temperatures are only included for species where this factor had a significant effect (Table 2, Table 3). For each species the solid lines represent germination trajectories of the treatments through time. Note the different scales on the y axis.

Figure 2. Observed germination in response to moist chilling and dormancy-breaking by gibberellic acid for 10 subalpine grassland forbs. In addition, and Ranuanculus platanifolius was also tested, but its germination was $<5 \%$ under all treatments and is not presented. Lab germination at $20^{\circ} \mathrm{C}$ and light, showing differences between fresh seeds, moist chilled seeds ( $4^{\circ} \mathrm{C}$ for two months), and moist chilled seeds treated with gibberellic acid. Within species and treatments, the mean percent germination in four replicate dishes $\pm 1 \mathrm{SD}$ is shown. For each species the solid lines represent germination trajectories of the treatments through time.

Figure 3. Illustration of the temporal seedling recruitment trajectories ( $\%$ of sown seeds present as alive seedlings) of 11 perennial grassland forbs in four experimental microsites during a two-year field experiment in subalpine grassland. Cut treatments refer to vegetation cutting height above ground and the vegetation sward in the uncut control is ca. $20 \mathrm{~cm} . \mathrm{S}=$ spring censuses, $\mathrm{A}=$ autumn censuses. 
Vandvik et al., - Recruitment-regulating mechanisms in subalpine grassland 

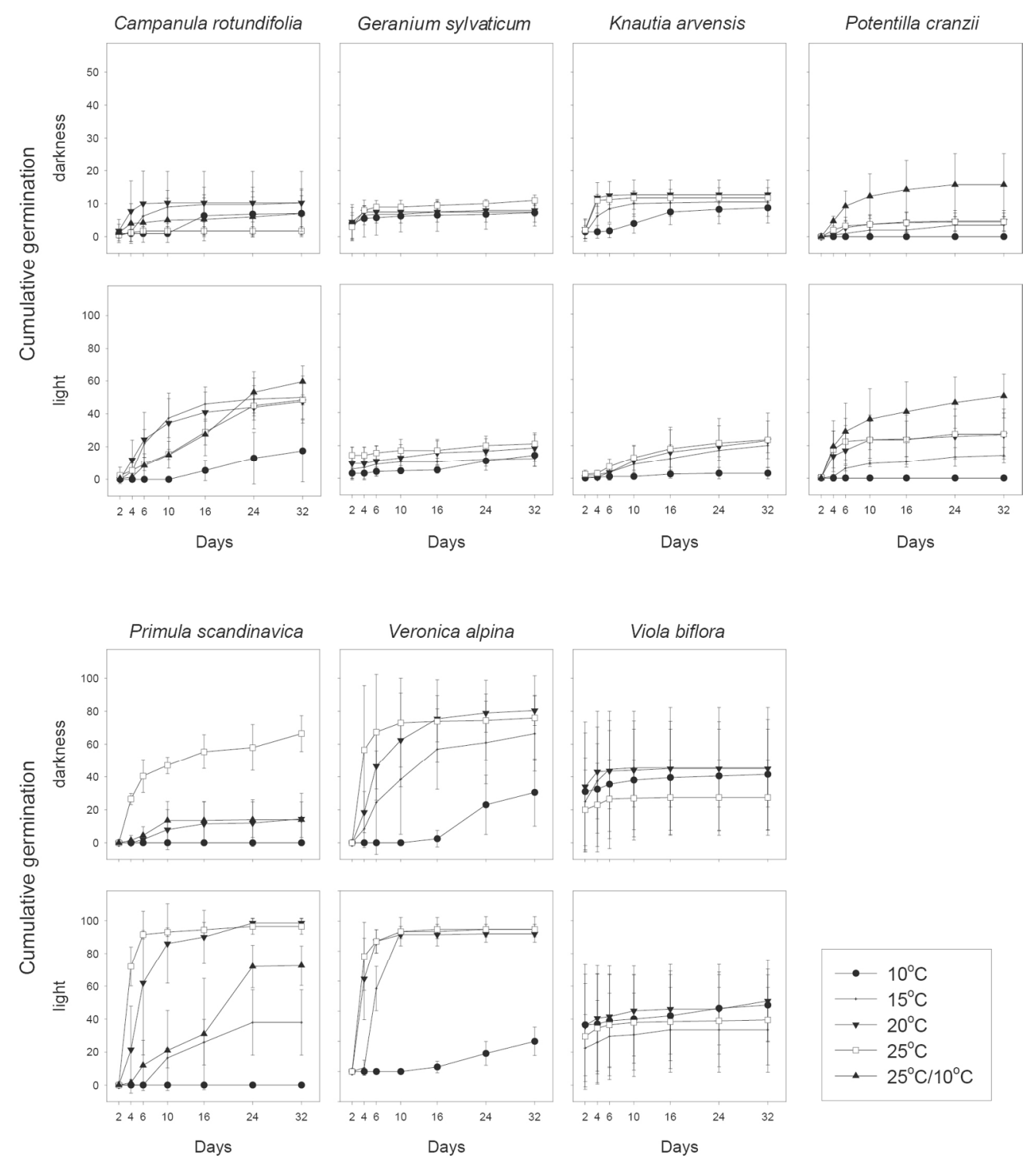

Figure 1. Observed germination in response to light and temperature on germination during the 32-day lab experiment for seven subalpine grassland forbs. Four additional species were tested (Comsastoma tenellum, Gentianella amarella, Trollius europaeus, and Ranunculus platanifolius) but these had germination $<5 \%$ under all treatments and are not presented. For each combination of species $\mathrm{x}$ light $\mathrm{x}$ temperature $\mathrm{x}$ census time, the mean percent germination in four replicate dishes \pm 1 SD is shown. Fluctuating $\left(25 / 10^{\circ} \mathrm{C}\right)$ temperatures are only included for species where this factor had a significant effect (Table 2, Table 3). For each species the solid lines represent germination trajectories of the treatments through time. Note the different scales on the $y$ axis.

$163 \times 193 \mathrm{~mm}(300 \times 300 \mathrm{DPI})$ 

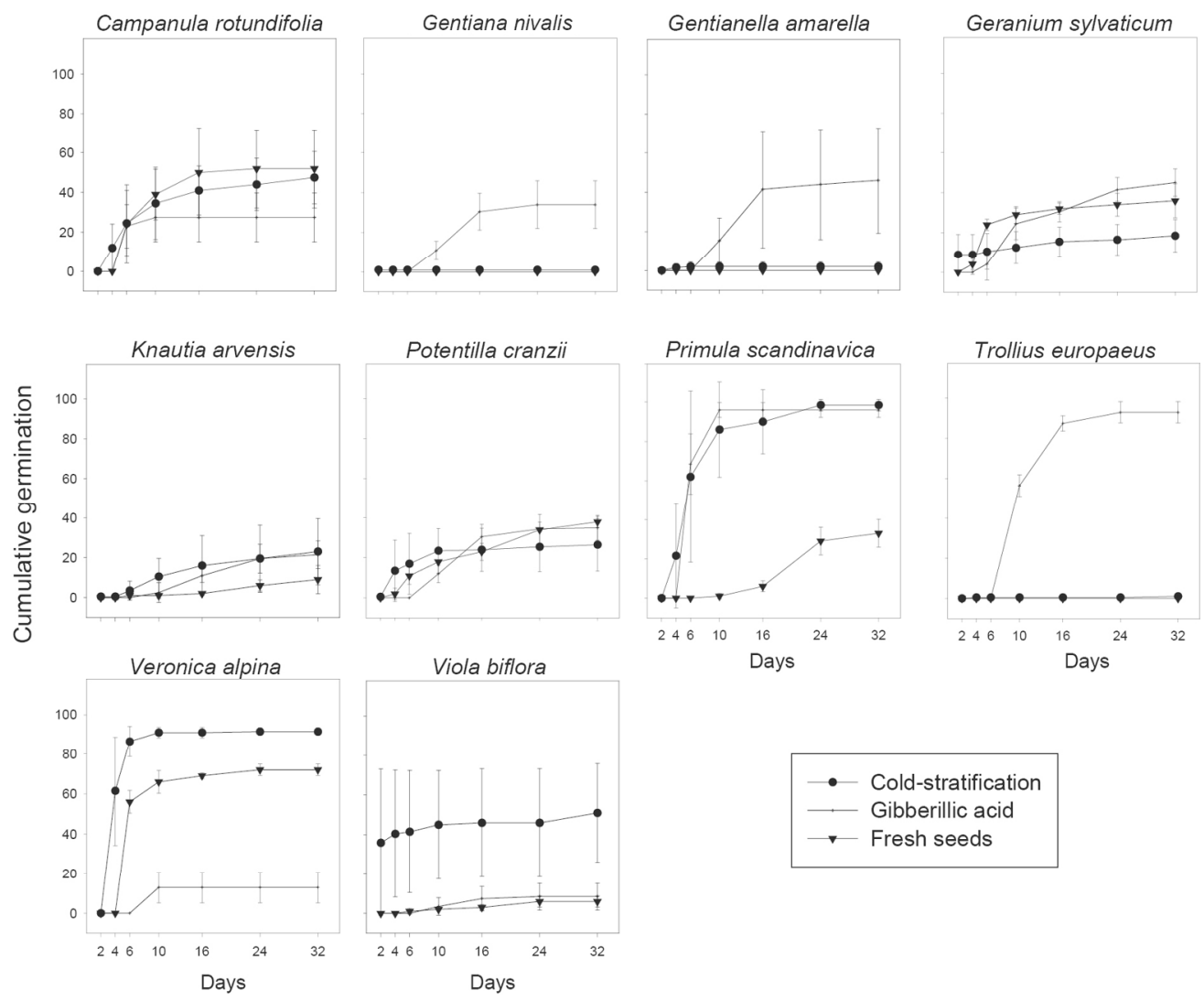

Figure 2. Observed germination in response to moist chilling and dormancy-breaking by gibberellic acid for 10 subalpine grassland forbs. In addition, and Ranuanculus platanifolius was also tested, but its germination was $<5 \%$ under all treatments and is not presented.

Lab germination at $20^{\circ} \mathrm{C}$ and light, showing differences between fresh seeds, moist chilled seeds ( $4^{\circ} \mathrm{C}$ for two months), and moist chilled seeds treated with gibberellic acid. Within species and treatments, the mean percent germination in four replicate dishes \pm 1 SD is shown. For each species the solid lines represent germination trajectories of the treatments through time.

$158 \times 130 \mathrm{~mm}(300 \times 300 \mathrm{DPI})$ 

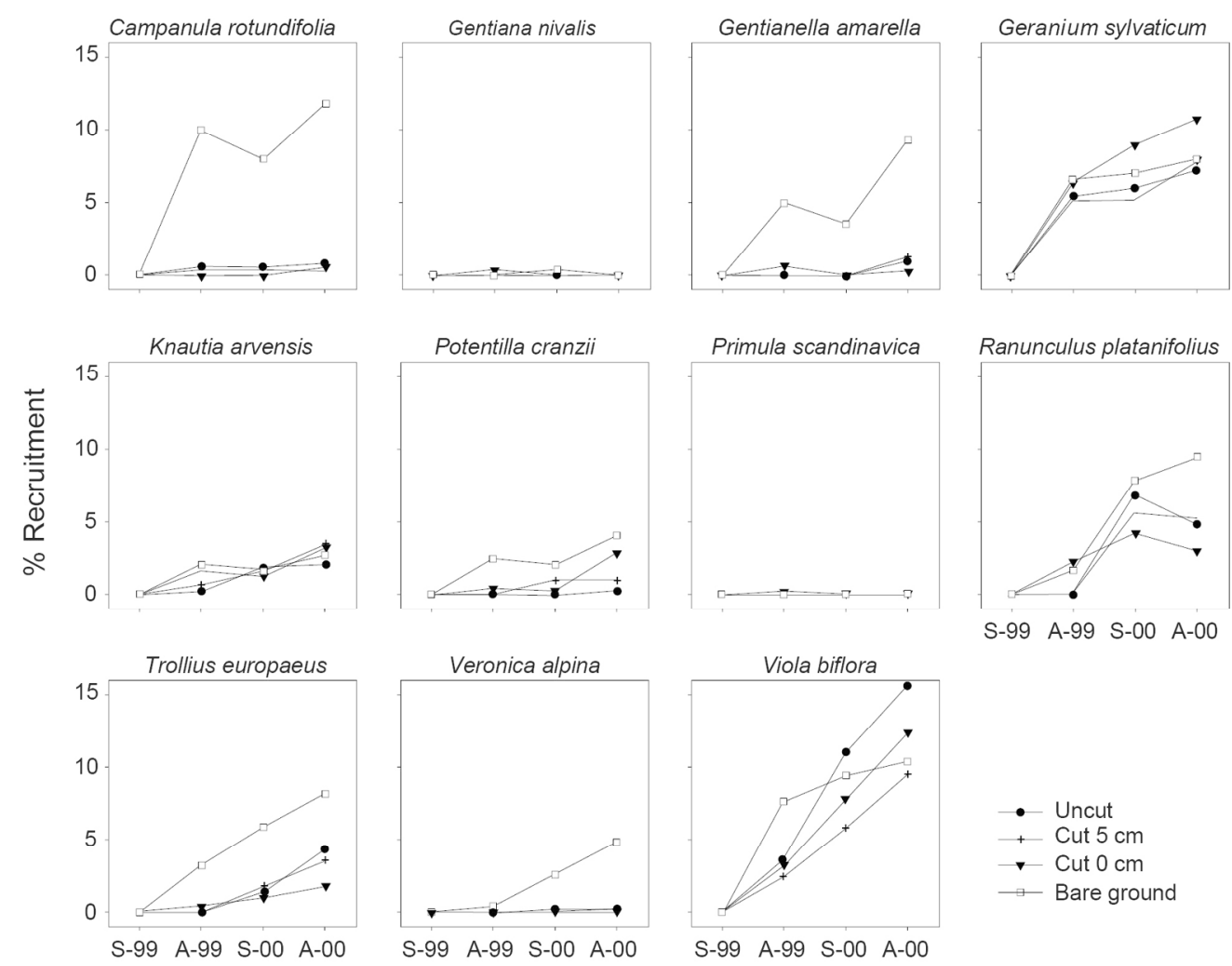

S-99 A-99 S-00 A-00

Figure 3. Illustration of the temporal seedling recruitment trajectories (\% of sown seeds present as alive seedlings) of 11 perennial grassland forbs in four experimental microsites during a two-year field experiment in subalpine grassland. Cut treatments refer to vegetation cutting height above ground and the vegetation sward in the uncut control is $\mathrm{ca} .20 \mathrm{~cm} . \mathrm{S}=$ spring censuses, $\mathrm{A}=$ autumn censuses.

$$
163 \times 128 \mathrm{~mm}(300 \times 300 \mathrm{DPI})
$$

